\title{
A Case Study of School Administrators’ Information Literacy
}

\author{
${ }^{\mathrm{a}}$ Wang Yajie, ${ }^{\mathrm{b}}$ Sun Honglin \\ ${ }^{a}$ Dept. Computer Teaching and Network Information Beijing University of Civil Engineering and Architecture \\ Beijing, China \\ ${ }^{b}$ Product Creative Center Beijing Siemens Cerberus Electronics Limited Beijing, China
}

\begin{abstract}
An investigation on the present situation of school administrators' information literacy in Beijing University of Civil Engineering and Architecture was carried out from information consciousness, information competence and information morality.The analysis on the investigation data was made. This paper afforded a referenced gist for information literacy education.
\end{abstract}

Index Terms: information literacy; school administrators; university and college; case study

(C) 2012 Published by MECS Publisher. Selection and/or peer review under responsibility of the International Conference on E-Business System and Education Technology

\section{Introduction}

The information age has emerged with the rapid development of information technologies and an increase in quantities of information, hence the need for people to develop essential information handling skills in academic, professional and private contexts. Effective learning, research, communication, decision making and problemsolving require that individuals are able to locate, manage, evaluate and use appropriate information from a wide range of formal and informal sources [1].

Within the development process of China higher education informationalization, the construction of teaching management informationization has been attached great importance to it as to improve administrative efficiency and service quality, to improve school management level and to actualize modernization of teaching management. The human factor is very crucial to the success of the construction of teaching management informationalization. The linchpin of the informationalization is to put the teaching management system into use and to serve the school management effectively. Besides, whether or not the school administrators have higher Information Literacy (IL) is also the key factor.

In this paper, a survey on school administrators' IL in Beijing University of Civil Engineering and Architecture (BUCEA) was conducted. The target was to discover the potential problem, analyze the causes and then gain the methods, by which the school administrators' IL can get improved. 


\section{Methodology}

IL is defined in the Australian and New Zealand Institute for Information Literacy (ANZIIL) Framework as the ability to recognize a need for information, determine the extent of information needed, access information efficiently, critically evaluate information and its sources; classify, store, manipulate and redraft information collected or generated; incorporate selected information into their knowledge base and use information effectively to learn, create new knowledge, solve problems and make decisions. Essentially, an information literate person can locate information relevant to a particular need from an appropriate source, judge its quality and 'fit-for-purpose' and then apply the information to the need in an ethical manner[2].

This study adopted the method of questionnaires, supplemented by individual interviews and observation. Based on the definition and standards of IL, and with the general understanding of IL, the questionnaire was designed, targeting at evaluating college administrators' information consciousness, information competence and information morality. SPSS software was adopted as the assistant tool for questionnaire data input and analysis.

The survey aimed at school administrators in BUCEA, 70 questionnaires were sent out with 65 copies returned. Recovery rate was $92.8 \%$, and 60 copies were valid.

\section{The Survey Results}

\section{1 Information Consciousness}

Information consciousness is the sum of understanding, concept and demanding, which generated during the information management activities. A good sense of information consciousness is a necessary basis and prerequisite for solving the problems using information technology. An individual with information literate is able to determine the extent and range of information he need. The questions involving information consciousness within this survey were shown in Table 1.

The results showed that the use of information technology for information acquisition, processing and applications were gradually becoming daily activities. Finding information, browsing news and communicating with others were the main purposes during BUCEA administrators' internet activities.

TABLE I. QUESTIONS OF INFORMATION CONSCIOUSNESS

\begin{tabular}{|c|c|c|}
\hline Dimension & Item & $\begin{array}{l}\text { Per-cen- } \\
\text { tage }(\%)\end{array}$ \\
\hline \multirow{4}{*}{ Information Requirement } & Know and access to work related web pages frequently & 70 \\
\hline & $\begin{array}{l}\text { Know a few work related web pages and forums, but rare to } \\
\text { use them. }\end{array}$ & 30 \\
\hline & Acquainted with the latest work related news periodically & 70 \\
\hline & Know the latest work related news occasionally & 30 \\
\hline \multirow{4}{*}{$\begin{array}{l}\text { Frequency } \\
\text { of information technology } \\
\text { use }\end{array}$} & Use computer each day & 96.7 \\
\hline & Use computer each week & 3.3 \\
\hline & Use internet each day & 90 \\
\hline & Use internet each week & 10 \\
\hline \multirow{7}{*}{ Goal of using internet } & Find information & 30 \\
\hline & Browse news & 27 \\
\hline & Communicate with others by email & 25 \\
\hline & Entertainment & 4 \\
\hline & Post in forum & 7 \\
\hline & Chat with live MSN/QQ & 9 \\
\hline & Online shopping & 6 \\
\hline
\end{tabular}

Research Fund of Beijing University of Civil Engineering and Architecture (Z08063) 


\section{2 Information Competence}

Information competence is how administrators collect, process and evaluate information during their daily work. It constitutes the core of IL, and is one of the most important skills. The effectiveness of administrators' work greatly depends on their information competence. Generally, it embodies the following aspects [3]:

- Access the needed information effectively and efficiently.

- Evaluate information and its sources critically.

- Incorporate selected information into one's knowledge base.

- Use information effectively to accomplish a specific purpose.

The information competence related problems were shown as table 2 .

Survey results showed that:

- When a problem occurred or need access to some certain resources, the most frequently used methods taken by the administrators was to search the internet or to consult colleagues, the usage of library was few.

- Regarding to the search engines, most administrators considered that they can skillfully use them. But as to the use of the download software and library index system, considerable numbers of administrators were not very familiar with them; some people even did not know how to use such tools.

- As to the information organizing and processing tools, most administrators mastered the use of Microsoft Office (Word, Excel, and PowerPoint).While the ability to employ drawing tools and web page making tools was weak.

- This showed that administrators were still lack of the abilities of information processing, sophisticated tools using, which were needed to integrate information to create in BUCEA.

TABLE II. QUESTIONS OF INFORMATION COMPETENCE

\begin{tabular}{|c|c|c|}
\hline Dimension & Item & $\begin{array}{l}\text { Per- } \\
\text { cen- } \\
\text { tage } \\
(\%)\end{array}$ \\
\hline \multirow{4}{*}{$\begin{array}{l}\text { Information access } \\
\text { methods }\end{array}$} & Consult other colleagues & 53.3 \\
\hline & Buy paper book or audiovisual materials & 20 \\
\hline & Investigate in library & 10 \\
\hline & Search in internet & 96.7 \\
\hline \multirow{4}{*}{$\begin{array}{l}\text { Information access } \\
\text { tool }\end{array}$} & $\begin{array}{l}\text { Use search engine adroitly, such as WWW.BAIDU.COM, } \\
\text { WWW.GOOGLE.COM }\end{array}$ & 93.3 \\
\hline & Use the library index system skillfully & 42.9 \\
\hline & Use HTTP/FTP download tool & 37 \\
\hline & Use the index tool provided by specialized database & 22.2 \\
\hline \multirow{4}{*}{$\begin{array}{l}\text { Information search } \\
\text { strategy }\end{array}$} & Only use one keyword & 12.9 \\
\hline & Use the keyword combination occasionally & 19.4 \\
\hline & Use the keyword combination frequently & 64.5 \\
\hline & No search engine use, just browse & 3.2 \\
\hline
\end{tabular}




\begin{tabular}{|l|l|c|}
\hline \multirow{3}{*}{$\begin{array}{l}\text { Information } \\
\text { Evaluation }\end{array}$} & $\begin{array}{l}\text { When the information obtained conflicts with the } \\
\text { original ,search more information for accurate understanding }\end{array}$ & 86.2 \\
\cline { 2 - 3 } & $\begin{array}{l}\text { When the information obtained conflicts with the } \\
\text { original ,accept new information }\end{array}$ & 13.8 \\
\hline \multirow{5}{*}{ Software } & $\begin{array}{l}\text { When the information obtained conflicts with the } \\
\text { original ,ignore new information and stick to the former point } \\
\text { of view }\end{array}$ & 0 \\
\hline & WORD & 100 \\
\cline { 2 - 3 } & EXCEL & 92.9 \\
\cline { 2 - 3 } & POWERPOINT & 85.7 \\
\cline { 2 - 3 } & Adobe Reader (PDF) & 71.4 \\
\cline { 2 - 3 } & Windows Painting & 28.6 \\
\cline { 2 - 3 } & Photoshop & 21.4 \\
\cline { 2 - 3 } & FLASH & 53.6 \\
\cline { 2 - 3 } & Special download tool & 17.9 \\
\cline { 2 - 3 } & Web pages making software(FrontPage、Dream weaver,etc.) & \\
\hline
\end{tabular}

\section{3 Information Morality}

Information morality is the moral guide lines within the information activities.

It is the sum of the code of conduct, which used to adjust the interrelationships among information creators, information service providers and information users. Its purpose is to promote individual members of society to follow certain morality and information code to regulate their information activity behaviors.

An information literate individual is able to understand the economic, legal, and social issues surrounding the use of information, and access and use information ethically and legally.

The information morality related problems were shown as table 3:

TABLE III. QUESTIONS OF INFORMATION MORALITY

\begin{tabular}{|c|c|c|}
\hline Dimension & Item & $\begin{array}{l}\text { Per-cen- } \\
\text { tage (\%) }\end{array}$ \\
\hline \multirow{3}{*}{$\begin{array}{l}\text { Consciousness of } \\
\text { copyright during } \\
\text { Literature quotation }\end{array}$} & It is necessary to list all literature in reference. & 62.1 \\
\hline & $\begin{array}{l}\text { It is only necessary to list all literature in reference in } \\
\text { important situation. Reference in general do not } \\
\text { usually be specified. }\end{array}$ & 37.9 \\
\hline & It does not matter specify the reference or not. & 0 \\
\hline \multirow[t]{3}{*}{$\begin{array}{l}\text { Proper use the } \\
\text { information got from } \\
\text { internet }\end{array}$} & $\begin{array}{l}\text { To determine the reasonable use of the information on } \\
\text { the network correctly, can judge infringement or } \\
\text { plagiarism. }\end{array}$ & 85.7 \\
\hline & Can not judge infringement or plagiarism. & 14.3 \\
\hline & Never considered whether infringement copyright. & 0 \\
\hline \multirow{2}{*}{$\begin{array}{l}\text { Commodity value of } \\
\text { information }\end{array}$} & $\begin{array}{l}\text { In case the urgent need,be willing to accept the paid } \\
\text { information services. }\end{array}$ & 44.8 \\
\hline & $\begin{array}{l}\text { Understandable paid information, but does not accept, } \\
\text { would continue to search for free information. }\end{array}$ & 41.4 \\
\hline
\end{tabular}




\begin{tabular}{|l|l|c|}
\hline \multirow{2}{*}{ Dimension } & \multicolumn{1}{|c|}{ Item } & $\begin{array}{c}\text { Per-cen- } \\
\text { tage (\%) }\end{array}$ \\
\hline & $\begin{array}{l}\text { Willing to accept paid information services at any } \\
\text { time. }\end{array}$ & 6.9 \\
\cline { 2 - 3 } & Willing to accept paid information services at no time. & 6.9 \\
\hline
\end{tabular}

The survey results showed that the administrators in BUCEA were still not realized that information was a valuable commodity in information society. Besides, consciousness of copyright was also in need of being strengthened.

\section{Conclusions and Recommendations}

\section{1 Conclusion}

We can draw the following conclusions based on the IL survey conducted on BUCEA administrators.

- As to the sense of information, BUCEA administrators could take the initiative to notice the development of information technology in education, could understand the content of IL comprehensively, could use information technology frequently for information acquisition, processing and application.

- As to the access to information, BUCEA administrators had considered the internet as the main information access channel. And there were more than half of the staff would consult their colleagues as the main channel to get information. Most administrators could use search engine effectively, with good information retrieval strategy for the information they need. However, for the traditional library resource, few administrators used it.

- As to information application and creation, BUCEA administrators had the dialectic thinking skills during the use of information application, and could use information to solve the related problems. With those skills, administrators are quite competent for their daily work, but the application level relatively low.

- As to the information morality, the sense of intellectual property protection needed to be further strengthened.

\section{2 Proposals}

Based on the analysis of the BUCEA administrators' IL status, we propose the following two suggestions to improve their IL:

1) Strengthen the construction of information environment and create a good information technology atmosphere.

Through investigation, we found that BUCEA administrators had considered the main factors restricting their IL development were limited learning time and lacking resources available. Besides, inner demanding (the information needs of their own) and external demand (school incentive and evaluation mechanisms) were also the important factors which would boost the administrators IL development. Information environment has an important influence on cultivating and improvement of people's information consciousness. It is out of the question for administrators to cultivate information consciousness without access to information technology. 
So building a good information environment is the material basis for cultivating and improving administrators' information consciousness. Information environment, including both the hardware and software environment, is very advantage to providing administrators with a variety of information resources, to improving there work efficiency and effectiveness. Information environment also includes the construction of information technology applications environment, which means to organize various seminars, to expand information technology application areas in the campus, to carry out information technology application competitions.

The information technology evaluation system is an essential part of the successful information environment. By setting up a corresponding evaluation system, administrators would be encouraged to consciously cultivate their IL during the daily learning and working process.

\section{2) Appoint "IL pilots "}

As to the question of how to improve administrators' IL, 76\% of the administrators hope to strengthen exchanges between colleagues and learn from each other; $62 \%$ wish to participate in seminars organized by the school from time to time; 55\% wish to participate in the periodic training. And only a few people choose the methods of self-study or participating in external training courses. Also it can be shown from the survey that the most preferred means is asking colleagues for support.

Therefore, it is necessary to set a part-time position of IL pilots, one for each department or for each office, with work shift every one year or two year. Such method would promote the improvement of management IL. Colleague should provide IL pilots with a common collaborative learning environment, should support them by accessing to various situations and forms of information technology trainings.

The IL pilots' responsibilities mainly involve collecting and solving those information technology related problems, which occurred during administrators' daily work. Besides, to improve peoples' information consciousness and to publicize the information ethics are also within their work category.

\section{References}

[1] Likonelo Constance M. Bitso , "Investigating information literacy skills and academic results of undergraduate students ”, http://www.innovation.ukzn.ac.za/InnovationPdfs/No21pp29-32Bitso.pdf

[2] Adrian Stagg and Michael Lane, "Using Clickers to Support Information Literacy Skills Development and Instruction in First-Year Business Students", Journal of Information Technology Education Vol. 9:2010 , pp.197-215 http://jite.informingscience.org/documents/Vol9/JITEv9p197-215Stagg800.pdf

[3] American Library Association, “The Information Literacy Competency Standards for Higher Education”, http://www.ala.org/acrl/ilcomstan.html

[4] Shazia Mumtaz, "Factors Affecting Teachers' Use of Information and Communications Technology: a review of the literature” , Journal of Information Technology for Teacher Education, Vol. 9, No. 3, 2000 pp.319-342, http://www.informaworld.com/terms-and-conditions-of-access.pdf

[5] Mark Hepworth Evans WemaThe, “design and implementation of an information literacy training course”, http://www.ics.heacademy.ac.uk/italics/vol5-1/pdf/hepworth-evans-final.pdf

[6] Sirje Virkus, “ Information literacy in Europe: a literature review”, http://informationr.net/ir/84/paper159.html

[7] Alan Bundy, “One essential direction: information literacy, information technology fluency", http://www.jelit.org/6/01/JeLit_Paper_1.pdf 